\title{
Notícias do Brasil colonial a imprensa científica e política a serviço das elites (Portugal, Brasil e Inglaterra)*
}

\author{
News from colonial Brazil \\ The scientific press and politics on \\ the elites' behalf (Portugal, Brazil e England)
}

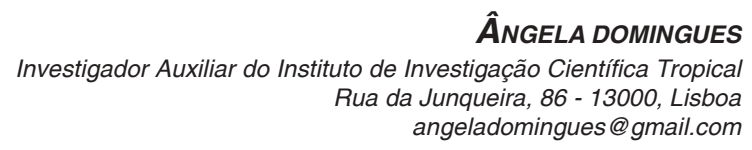

RESUMO Este artigo analisa o minucioso processo de recolha de informação sobre a colónia brasileira através das notícias divulgadas por um jornal científico, as Philosophical Transactions, órgão oficial da Royal Society (Londres), bem como o papel desempenhado por diplomatas, cientistas, académicos e comerciantes residentes em Inglaterra na construção da imagem do Brasil antes desse marco cronológico tradicionalmente apontado pela historiografia oficial como "o início de todas as mudanças": 1808.

Palavras-chave Iluminismo, Philosophical Transactions, História da Ciência

ABSTRACT This article analyzes the minute process of collecting information on the Brazilian colony through the news divulged by a scientific

Artigo recebido em 02/11/2005. Aprovado em 14/12/2005. 
periodical, Philosophical Transactions, the official organ of the Royal Society in London, as well as the role played by diplomats, scientists, academics and businessmen living in England in the construction of the image of Brazil before the chronological marker traditionally pointed to by official historiography as "the beginning of all the changes": 1808.

Key words Enlightenment, Philosophical Transactions, History of Science

Alguns autores contemporâneos afirmam que a descoberta científica do Brasil pelos europeus data dos inícios do século XIX. Segundo eles, só após 1808, com a abertura dos portos brasileiros aos ingleses e, nos anos sucessivos, às populações de outros países europeus e, sobretudo, através das descrições de viajantes franceses, alemães, russos e ingleses, indivíduos esclarecidos, lúcidos, dinâmicos e inovadores, se teria iniciado o processo de revelação do Brasil a uma Europa setecentista e oitocentista, curiosa em conhecer os novos mundos que the eram revelados através das grandes viagens da época e divulgados por uma imprensa activa e incansável na publicação da literatura associada a essas viagens.

Contudo, importa reconhecer que, ao longo do século XVIII, há um esforço enorme, desenvolvido por uma elite ao serviço da ciência e dos estados europeus, para obter informações sobre os domínios sulamericanos do Rei Fidelíssimo. Se é inegável o peso do controle e da censura portugueses em relação à divulgação de informação sobre domínios que pela sua importância estratégica, política, económica, militar se queriam resguardar, importa igualmente assinalar que qualquer dado obtido sobre esta área geográfica — sob a forma de texto, imagem, carta, objecto, produção natural - era considerado, avaliado, estudado e comparado com outros casos ou 'universos' conhecidos. Neste artigo pretendemos analisar este minucioso processo de recolha de informação sobre a colónia brasileira através das notícias divulgadas por um jornal científico, as Philosophical Transactions, órgão oficial da Royal Society (Londres), bem como o papel desempenhado por diplomatas, cientistas, académicos e comerciantes residentes em Inglaterra na construção da imagem do Brasil antes desse marco cronológico tradicionalmente apontado pela historiografia oficial como "o início de todas as mudanças": 1808.

Pretendemos, seguidamente, verificar como essa imagem se vai alterando, mas não através dos relatos de viagens dos naturalistas estrangeiros, vias normalmente utilizadas para analisar tal mudança. Na segunda parte deste artigo, o nosso objectivo consiste em compreender como uma elite cultural emigrada portuguesa e luso-brasileira utilizou a 
liberdade de imprensa existente em Inglaterra para divulgar ideias e defender princípios ideológicos que, no reino, seriam objecto de censura, tendo em vista a 'formação' e 'informação' dos povos, a nível político, cultural e económico; e também analisara forma como esta elite usou os jornais para se organizar em redes que permitiram a circulação consertada e mais ampla de notícias. Estas redes eram constituídas por indivíduos com programas ideológicos e ambições políticas semelhantes: os ilustrados ibéricos e latino-americanos residentes em Londres.

Em pleno período das Luzes, quando se renovava a consciência que os europeus tinham do Novo Mundo e quando 'filósofos naturalistas' como Adam Smith ou Samuel Engel questionavam a credibilidade dos testemunhos de 'soldados ignorantes' e 'clérigos inábeis' que, nos séculos XVI e XVII, tinham viajado e vivido na América, esta mesma Europa curiosa e interessada continuava, todavia, a utilizar os escritos de autores de quinhentos e seiscentos, como Jean de Léry (Histoire d'un voyage faict en la tere du Bresil, 1578), André Thévet (Les singulatités de la France Antarctique, 1557 e Cosmographie Universelle, 1575), Hans Staden (Wahrhaftige Historie, Marburgo,1557) e Claude d'Abeville (Histoire de la mission des pères capucins en l'isle du Maragan et terres circonvoisines, Paris, 1614) para se referir ao Brasil. Os Sermões do jesuíta António Vieira e a obra de Fernão Cardim (A treatise of Brazil written by a Portugal which long live there, editado por Samuel Purchas, Londres, 1625), continuavam a ser referências intelectuais no que tocava aos domínios sulamericanos de Sua Majestade Fidelíssima. ${ }^{1}$ Willem Piso, Georg Marcgrave e a Historia Naturalis Brasiliae (Amsterdão, 1648) eram ainda autoridades quando se tratava de assuntos tão díspares como a ipecacuanha, suas características físicas e propriedades eméticas, ou a migração de andorinhas em território americano.

Durante largo período de tempo, sobretudo a partir de inícios do século XVIII, a imagem que a Europa Setecentista tinha da colónia brasileira foi condicionada pela falta de informações actualizadas. A indefinição de limites tanto no rio da Prata com os espanhóis, quanto a Norte com os franceses da Guiana e os conflitos armados em que esta tensão fronteiriça, por vezes, se traduzia; o medo de ataques militares às principais cidades do litoral; as rebeliões internas que eclodiram nas Minas, Baía e Pernambuco, em muitos casos associadas a revoltas fiscais; e, acima de tudo, a existência de ouro no interior do Brasil foram razões mais que suficientes para que a coroa defendesse ciosamente o conhe-

1 CAÑIZARES-ESGUERRA, Jorge. How to write the History of the New World. Histories, epistemologies and identities in the eighteenth century Atlantic world. Stanford: Stanford University Press, 2001, p.11-13; DOMINGUES, Ângela. Viagens cientificas e divulgação cartográfica. In: GARCIA, João Carlos. (coord.). A Nova Lusitânia. Imagens cartográficas do Brasil nas colecções da Biblioteca Nacional (1700-1822). Lisboa: Comissão Nacional para as Comemorações dos Descobrimentos Portugueses, 2001, p.67 e ss. 
cimento do território e os segredos da sua ocupação - geografia, acessos, riquezas minerais e potencialidades de desenvolvimento agrícola e pecuário, demografia, urbanização e recursos defensivos. Sabia-se que a notícia do achamento de produtos preciosos despertava o apetite de estrangeiros pelo território, como aliás os ataques de Du Clerc (Setembro de 1710) e René Du Guay-Trouin (Junho de 1711) ao Rio de Janeiro tinham comprovado. ${ }^{2}$ Temia-se que mesmo a acção conjugada de forças marítimas, tropas profissionais e milícias de ordenanças não fosse suficiente para conter uma invasão planeada do território brasileiro por parte de uma potência européia. ${ }^{3}$

O controle que a coroa portuguesa mantinha sobre território colonial não se traduziu unicamente nos constrangimentos jurídicos impostos à presença e circulação de estrangeiros no território; ${ }^{4}$ nem, tão pouco, nas proibições de escala de navios pertencentes a outras nações europeias em portos brasileiros e de comércio entre os naturais da terra e as tripulações. ${ }^{5}$ Os portugueses não publicavam ou divulgavam informação sobre estes territórios, mantendo inéditos os manuscritos e submetendo a uma divulgação restrita os textos editados. Esta foi uma opção política consciente da coroa portuguesa, que se manifesta de forma clara numa cópia de uma consulta do Conselho Ultramarina, datada de 1711, determinando que "Parece que será muito útil ao Real Serviço de V. Majestade ondenarse que daqui em diante se não possa imprimir livro algum em que se tratem de matérias pertencentes às Conquistas sem que tenhão, com as mais licenças, também a deste Tribunal, porque nelle como miIhor instruido nos particullares delles e que tem por obrigação zellar e advertir o que lhe poderá estar milhor para a sua concervação e augmento se pode ter por mayor conhecimento do que convem e se divulgue do que importa que não chegue à notícia das nações estrangeiras". ${ }^{6}$ Um exemplo paradigmático desta situação é, como bem o demonstra o estudo introdutório de Andrée Mansuy Diniz Silva à Cultura e opulência do Brasil por suas drogas e minas, a destruição do livro de

2 DU GUAY-TROUIN. O Corsário. Uma invasão francesa no Rio de Janeiro. Memórias do Senhor Du GuayTrouin, comandante-geral da armada de França e comendador da Ordem Real e Militar de São Luís. Diário de bordo. Rio de Janeiro: Bom Texto, 2002.

3 BICALHO, Maria Fernanda Baptista. Quotidiano, medo, revolta e poder no Rio de Janeiro no século XVIII:um estudo sobre as invasões. In Do Tratado de Tordesilhas (1494) ao Tratado de Madrid (1750), Lisboa: Sociedade de Estudos do Século XVIII, 1997, p.311-321.

4 V. por exemplo, carta régia ordenando ao governador de São Paulo e Minas o embarque para o reino de todos os estrangeiros, com excepção de ingleses e holandeses, que estivessem sob seu governo, datada de 25 de Fevereiro de 1711 e carta régia ordenando que fossem tolerados os estrangeiros casados com portuguesas, que tivessem filhos e não fossem homens de negócio, de 7 de Abril de 1713 (Biblioteca Nacional do Rio de Janeiro, 1-2-14)

5 BICALHO, Maria Fernanda. A cidade e o império. O Rio de Janeiro no século XVIII. Rio de Janeiro: Civilização Brasileira, 2003, p.35.

6 SILVA, Andrée Mansuy Diniz. Introdução. In: ANTONIL, André João. Cultura e opulência do Brasil por suas drogas e minas. Lisboa: Comissão Nacional para as Comemorações dos Descobrimentos Portugueses, 2001 p.52. 
André João Antonil, ordenada pelo rei D. João V em nome da razão de Estado. $^{7}$

Da mesma forma, a consulta de informações depositadas nos arquivos públicos, como a Biblioteca Nacional e a Academia Real das Ciências de Lisboa por estrangeiros que visitavam Portugal ou que pertenciam ao corpo diplomático creditado era condicionada. O testemunho de um inglês célebre, Robert Southey, que visitou Portugal em 1796 e 1800 e 1801, é elucidativo da situação: "(...) you need not be told what an absurd secrecy they hide from the word all information respecting that country: the population of Brazil is said to double that of the mother, and now dependent, country". 8

Medidas restritivas de ordem jurídica, secundadas por uma eficaz actividade de censura, condicionam, durante largo tempo, a informação que a Europa tinha sobre a América.

Em contrapartida, e como acima se referiu, verifica-se no mesmo período um aumento do interesse público pelo continente americano. No dealbar de setecentos assiste-se não só à publicação de colectâneas de literatura de viagens ocorridas nos dois séculos anteriores, como se verifica que estas mesmas fontes são utilizadas profusamente como veículos de informação acerca dos territórios ibéricos na América do Sul. É certo que, na medida em que eram detentores de textos construídos sem o racionalismo, o esclarecimento, a 'cientificidade' e observação rigorosa proporcionada por instrumentos mecânicos indispensáveis ao entendimento dos homens do século das Luzes, os autores e editores de histórias, relações geográficas, memórias científicas e obras cartográficas procuravam confirmar e completar a informação que Ihes era veiculada pelos textos de quinhentos e seiscentos.

Na prossecução deste objectivo, utilizava-se, sempre que possível, a observação directa, preferencialmente apoiada na utilização de 'tecnologia de ponta'. As viagens de marinheiros e traficantes, de piratas e corsários ao litoral brasileiro eram criteriosamente registadas, tomando a forma de textos escritos, vistas e mapas que contribuíram significativamente para uma noção mais correcta e precisa dos portos e dos contornos costeiros do Brasil. A viagem à América do Sul de A:F. Frezier, um hidrógrafo ao serviço do rei de França, permitiu corrigir a representação cartográfica do litoral brasileiro, atribuindo-lhe uma longitude mais exacta, e facultou um melhor conhecimento da configuração da ilha de Santa Catarina e do recôncavo baiano. ${ }^{9}$

7 ANTONIL, André João. Cultura e opulência do Brasil por suas drogas e minas, p.43-55.

8 Carta de Robert Southey a John Rickman, datada de 30-31 de Outubro de 1800. In: SOUTHEY, Robert. Journals of a residence in Portugal (1800-1801) and a visit to France (1838), supplemented by extracts from his correspondence. Oxford: the Clarendon Presse, 1960, p.138.

9 FREZIER, M. De. Relation du voyage de la mer du Sud aux côtes du Chily et du Perou fait pendant les années 1712,1713 \&1714. Paris : Chez Jean-Geoffroy Nyon, Etienne Ganeau, Jaques Quillau, 1716, p.XI-XII. 
A cartografia renovava-se com as observações directas da geografia costeira feitas por pilotos, viajantes, aventureiros e corsários, conjugadas com as medições das coordenadas terrestres por novos apareIhos de precisão. Fenómenos naturais avistados no litoral brasileiro, como o fogo-de-santelmo, eram pormenorizadamente descritos, lamentandose, em muitos casos, o facto de as observações serem feitas a olho nu.

Se houve progressão e actualização no conhecimento que se tinha do litoral, pouco se sabia do espaço que não se avistava da linha de água e da natureza e da humanidade que ocupavam o maciço continental sul-americano. A informação sobre a colónia brasileira era diminuta, maioritariamente baseada em autores de quinhentos e seiscentos e a extrapolação de observações relacionadas com a fauna, flora, mineralogia e a humanidade de outros locais que tivessem características físicas semelhantes era uma prática legitima destinada a preencher lacunas. Assim se compreende a relevância que foi dada por Mr. La Harpe no Abrégé de l'Histoire Générale des Voyages à descrição dos insectos do Suriname por Maria Sibylla Meriam (1699). ${ }^{10}$ O Metamorphosis insectorum Surinamensium, publicado em Amsterdão em 1705, foi utilizado com profusão por La Harpe para tornar mais tangível um espaço quase desconhecido - a colónia brasileira — à curiosidade e às exigências de um público ilustrado.

\section{O caso das Philosophical Transactions}

O estudo sistemático de uma publicação oficial de uma sociedade científica de grande influência na Europa — as Philosophical Transactions, editadas pela britânica Royal Society — confirma não só o interesse que as colónias sul-americanas suscitavam, quando a deficiente e manipulada informação disponível sobre o assunto, mercê do controlo oficial a que aludimos. As Philosophical Transactions definem-se como a 'publicação oficial' de uma sociedade científica selecta sem fins económicos ou utilitários que pretendia ser pioneira na observação e experimentação científica acerca da Inglaterra e do Império Colonial Inglês. ${ }^{11}$

A Royal Society caracteriza-se, na segunda metade de Setecentos, por ser uma instituição supranacional constituída por uma elite aristocrá-

10 LA HARPE, Mr. Abrégé de l'Histoire Générale des Voyages contenant ce qu'il y a de plus remarquable, de plus utile \& de mieux avéré dans les Pays où les voyageurs ont pénétré ; les mours des Habitants, la Religion, les Vsages, Arts \& Sciences, Commerce, Manufactures; enrichie des Cartes géographiques \& des figures. Paris: Hotel de Thou, 1780, vol.1, p.I.

11 Sobre outros espaços de sociabilidade londrina com vista à educação de massas e à divulgação científica e técnica junto de um público menos elitista, maioritariamente composto por arquitectos, engenheiros, construtores navais, relojoeiros e médicos cf. MORTON, AQ. Lectures on natural philosophy in London, 1750-1765 SCT Demainbray (1710-1782); Innatention of his countrymen, British Journal for the History of Science, vol.23, 4, p.411-430, Dezembro 1990. 
tica e científica, composta por "every one of His Magesty's subjects, who is a Peer, or son of a Peer, of Great Britain or Ireland, and every one of his Magesty's Privy Council of either of the said kingdoms; and every Foreign Sovereign Prince, or the son of a Sovereign Prince or an Ambassador to the Court of Great Britain", e que demonstrassem uma formação intelectual sólida e um reconhecido interesse em ciências naturais, matemáticas e "polite litteratures". ${ }^{2}$ Incluía não só indivíduos residentes em Inglaterra, mas também correspondentes de outras partes do Império Britânico ou do estrangeiro, por vezes estrategicamente colocados para suprir a Society de informações relacionadas com o ultramar.

As Philosophical Transactions, editadas desde 1665, destinavam-se a difundir e legitimar junto de uma elite científica nacional e europeia o rigor, civilidade, metodologia e objectividade do trabalho científico e experimental realizado pelos fellows e colaboradores da Society. ${ }^{13}$ Neste processo, a Royal Society actuava como um centro crítico de recolha de informações, um local a partir do qual se coordenava uma rede constituída por indivíduos actuantes em todas as partes do mundo, interessados em filosofia natural e história natural. ${ }^{14}$

As estreitas relações diplomáticas e comerciais mantidas de longa data entre Inglaterra e Portugal explicam a existência de uma comunidade britânica numerosa e próspera nas cidades de Lisboa e Porto. Os ingleses protegidos por tratados, tinham um estatuto especial face a outras comunidades: gozavam de benefícios comerciais e fiscais, beneficiavam de liberdade religiosa e tinham as suas próprias igrejas, hospitais, cemitérios e espaços de sociabilidade. ${ }^{15}$ Do mesmo modo, ocupavam uma posição privilegiada para adquirirem informações de natureza científica sobre o reino e as colónias portuguesas e, assim, colaborar com a Royal Society. Deste modo se pode explicar a concessão do estatuto de fellow a ingleses residentes em Portugal. Gilbert Kennedy, médico em Lisboa e interessado em história natural, foi admitido como fellow em 1737 e John Williamson, capelão da comunidade britânica na capital, foi FRS em 1749. ${ }^{16}$

Do mesmo modo, e como se depreende das determinações já enunciadas, a Royal Society admitiu, pelo menos desde os anos vinte, um número considerável de portugueses, diplomatas, políticos ilustres e

12 HOME, R. W. The Royal Society and the empire: the colonial and commonwealth fellowship. Part I, (17311847), Notes and records of the Royal Society of London, vol. 56 (3), p.313, 2002.

13 JOHNS, Adrian. Micellaneous methods: authors, societies and journals in early modern England, The British Journal for the History of Science, Part II, 33, № 116, p.165, Junho 2000.

14 RUSNOCH, Andrea. Correspondence networks and the Royal Society, 1700-1750, The British Journal for the History of Science, Parte II, 32, ํo 113, p.156, Junho 1999.

15 MAXWELL, Kenneth. Eighteenth-century Portugal: faith and reason, tradition and innovation during a Golden Age. In: The Age of the Baroque in Portugal, edição de Jay A. Levenson. Washington: New Heaven e Londres, National Gallery of Art, Yale University Press, 1993, p.106-107. 
homens de ciência notáveis ligados à Medicina, Literatura, Matemática, Filosofia Natural, Mecânica. António Galvão, embaixador em Londres entre 1726 e 1730, entrou na academia em 1725, D. Francisco Xavier de Meneses, quarto conde da Ericeira, foi FRS em 1738; Sebastião José de Carvalho e Melo foi admitido em 1740, João Mendes Saquet Barbosa, médico no hospital de Elvas e membro da Academia de Madrid, em 1750, Martinho de Melo e Castro, D. João Carlos de Bragança, duque de Lafões, e o oratoriano Teodoro de Almeida foram FRS em 1757, João Jacinto de Magalhães, membro correspondente da Real Academia de Ciências de Paris, foi admitido em 1774 e José Correia da Serra, que era membro da Real Academia de Ciências e Letras de Pentonville, foi integrado em 1795. ${ }^{17}$

Estes indivíduos participavam na vida académica, colaboravam nas Philosophical Transactions e, de forma preferencial, alargavam as redes de contactos centralizadas pela Royal Society a Portugal e às suas colónias através das suas relações pessoais.

Esta estratégia de recrutamento de fellows entre estrangeiros residentes e britânicos correspondentes permitia à Royal Society cumprir um dos seus propósitos, tal como era expresso por Henry Oldenberg desde o século XVII: "we have taken to taske the whole Universe and it will therefore be requisite, that we purchase and entertain a commerce in all parts of ye world with the most philosophical persons, to be found every where". ${ }^{18}$

Por seu turno, muitos dos fellows portugueses residentes em Londres faziam a ligação entre os universos desiguais dos dois países a nível científico e tecnológico, com Portugal a comprar livros, material cartográfico e equipamento técnico a Inglaterra. Um dos intermediários neste processo foi João Jacinto de Magalhães (FRS 1774). ${ }^{19}$

Nas memórias publicadas nas Philosophical Transactions durante o período considerado neste ensaio divulgavam-se as experiências e as teorias mais actualizadas em todos os campos do saber - Botânica, Astronomia, Física, Biologia, Etnologia, Medicina, Anatomia, Meteorolo-

16 HOME, R. W. The Royal Society and the empire: the colonial and commonwealth fellowship, p.315.

17 Royal Society, Lista de fellows da Royal Society. Muitas destas candidatures são apoiadas por Jacob Sarmento de Castro e Isaac de Sequeira Samuda.

18 "The ideal of scientific collaboration: the "man of science and the diffusion of knowledge". In: BOTS, Hans e WAQUET, Françoise. Commercium Litteratium. La communication dans la Republique des Lettres (1600 1750), Conférences des Colloques tenues à Paris 1992 et à Nimègue 1993. Amesterdão/ Maarssen: APA Holland University Press, 1993, p.12.

19 MALAQUIAS, Isabel Maria e THOMAZ, Manuel Fernandes. Scientific communication in the XVIII th century: the case of John Hyacinth de Magellan, PHYSIS, Rivista Internazionale di Staria della Scienza, vol. XXXI Nuova Serie, fasc.3, 1994; MALAQUIAS, Isabel Maria e THOMAZ, Manuel Fernandes. João Jacinto de MagaIhães: a sua obra impressa e a sua correspondência científica. Separata da Revista da Universidade de Aveiro/Letras, no 4-5, 1987-1988; MASON, Stephen F. Jean Hyacinthe de Magellan FRS and the Chemical Revolution of the eighteenth century, Notes and Records of the Royal Society of London, 45 (2), p.155-164,1991. 
gia, Paleontologia, Filosofia Natural, História, Trigonometria, Matemática, Óptica, Hidrostática, Magnetismo - , efectuadas pelos membros da Society e por intelectuais e cientistas vinculados a academias e universidades nacionais e estrangeiras. ${ }^{20}$

Para avaliarmos a participação que este periódico teve na construção da imagem do Brasil junto da elite culta europeia há, antes de mais, que considerar que o número de artigos relacionados com a colónia americana de finais do século XVII (vol. 20, 1698) até inícios do século XIX (vol. 113, 1823) foi irrisório: três artigos referindo plantas medicinais brasileiras, três relatos de viagens onde se mencionam observações oceânicas ao largo da costa brasileira, seis memórias descrevendo experiências com gemas e metais preciosas e ferro e quatro referências relacionadas com a história natural e produções naturais da América.

A informação utilizada pelos autores das memórias publicadas nas Philosophical Transactions era proveniente dos testemunhos dos que, em tempos idos, observaram directamente o Brasil. Assim, para descrever a ipecacuanha, o médico Hans Sloane socorria-se, em 1698, de Piso, Marcgrave, Jean de Laet e Fernão Cardim, referido como um anónimo português que vivera no Brasil e "whose look falling into the hands of the English is translated and published by Purchas in the year 1625". ${ }^{21}$ Do mesmo modo, Marcgrave era, em 1748, a referência científica na descrição da andorinha brasileira (Hirundo cauda aculeata Americana). ${ }^{22}$ E na confirmação da existência de perús no Brasil: evocava-se, primeiramente, Jean de Léry, erroneamente considerado como "a Portuguese author", que os descrevia e referia o nome ameríndio; depois questionavase a sua existência porque Marcgrave, "that diligent and excellent naturalist", não os mencionava; e acabava-se concluindo que existiam porque "that able and honest navigator Dampier, who saw them frequently, as well wild or tame, in the province of Yucatán, now reckoned part of the kingdom of México". ${ }^{23}$

Um aspecto que nos parece ser de realçar é que, desde os anos trinta, as Philosophical Transactions publicaram memórias sobre minerais brasileiros. A primeira notícia foi publicada nos inícios de 1730 e era composta por uma descrição das jazidas de ouro e diamantes de Serra

20 Considera-se, aliás, como verdadeiramente impressionante a extensa rede de ligações e de intercâmbio científico que a Royal Society mantinha com instituições congéneres em São Petersburgo, Paris, Berlim, Viena, Módena, Verona, Pádua, Pavia, Filadélfia, Gottinger, Irlanda, Dresden, Harlem, Estocolmo, Ruão, Brunswick, Copenhaga, Batávia, Lisboa, etc.

21 SLOANE, Hans MD. Of the use of the root Ipecacuanha for loosenesses, translated from a French paper: with some notes on the same by ...,Philosophical Transactions, vol.20, p.69-79, 1698.

22 CATESBY, Mark FRS. A continuation of an account of an Essay towards a Natural History of Carolina and the Bahama Islands, by ... with some extracts out the Appendix, by C Mortimer, Secret RS, Philosophical Transactions, vol.45, p.157-173, 1748.

23 PENNANT, Thomas Esq. FRS. An account of the turkey. By..., communicated by Joseph Banks, Philosophical Transactions, vol.71, 1781. 
Frio por um cavalheiro anónimo, considerado por Jacob de Castro Sarmento como "the fittest Person to describe every minute Circumstance of it, as one that liv'd and digg'd Gold there for these fifteen Years last past". ${ }^{24}$ Outras foram publicadas nos anos subsequentes e resultavam de experiências laboratoriais realizadas com amostras trazidas por membros da Royal Society, como Emanuel Mendes da Costa, admitido em 1747 como "a Gentleman well skilled in Philosophical Learning and Natural Knowledge, particularly in what relates to the Mineral and Fossil pasrts of the creation; as one exceedingly diligent in his enquiries and who applying imself with great assiduity to the Study of Natural History", ou por diplomatas portugueses, como Domingos António de Sousa Coutinho. ${ }^{25} \mathrm{O}$ interesse subjacente a estas memórias feitas pelos membros da instituição real era mais intelectual que prático e consistia em analisar as características, grau de pureza e valor das pedras, tendo como referência as do Oriente e das minas da Suécia e Alemanha; destinava-se, ainda, a comprovar a existência de novos espécimens minerais. Os minérios brasileiros faziam parte das colecções da Royal Society. ${ }^{26}$

As memórias sobre espécimens vegetais brasileiros publicadas nas Philosophical Transactions são irrisórias, sobretudo quando se considera a curiosidade e o interesse que a Europa setecentista tinha por produtos americanos passíveis de contribuir para o enriquecimento da farmacopeia ocidental e o desenvolvimento industrial. ${ }^{27} \mathrm{~A}$ explicação reside no facto de, na América do Sul, a observação directa do terreno e a recolha de espécimens vegetais serem proibidas pelos governos português e espanhol aos estrangeiros. Estas limitações estão na origem dos violentos protestos de um jovem Joseph Banks, botânico da expedição da primeira viagem de Thomas Cook e do Endeavour quando foi impedido de desembarcar pelo vice-rei do Brasil na capital da colônia; ${ }^{28}$ e foram, de novo, comprovadas em 1814, pelos colectores James Bowie e Allan Cunningham que, ao serviço dos Jardins de Kew e sob instruções de Banks, deviam recolher amostras nos arredores do Rio de Janeiro, Serra dos Orgãos e São Paulo e fazer observações sobre o seu uso na farmacopeia, culinária e indústria. ${ }^{29} \mathrm{E}$, talvez uma tentativa de ultrapas-

24 A letter from Jacob de Castro Sarmento, MD and FRS to Cromwell Mortimer, MD Secretary RS concerning diamonds lately found in Brazil, Philosophical Transactions, vol.37, p. 199-201, 1731-1732.

25 Royal Society, Lista dos fellows admitidos à Society; WOLLASTON, William Hyde MD, sec RS. On Platina and native Palladium from Brazil. By..., Philosophical Transactions, vol.99, p.189, 1809.

26 DAVY, Sir Humphrey, Brat, PRS. On the state of water and aeriform matter in cavities found in certain crystals, by..., Philosophical Transactions, vol.112, p.376, 1822.

27 DOMINGUES, Ângela. Os descobrimentos portugueses e a sua influência na medicina européia, CAR-Revista de Anestesia Regional e Terapêutica da Dor, no.35, p.10, Março 2004.

28 Querendo desembarcar no Rio de Janeiro, foi impedido pelo vice-rei que encarava a expedição com grandes reservar e alguma desconfiança (MACKAY, David. Agents of empire: the Banksian collectors and evaluation of new lands. In: MILLER, David Philip e REILL, Peter Hanns. Visions of Empire. Voyages, botany and representations of nature. $2^{\underline{a}}$ edição. Cambridge: Cambridge University Press, 1998, p.45).

29 O facto parece algo estranho e a sua confirmação não foi possível. David Mackay afirma que, apesar da 
sar estas limitações, através de propostas de intercâmbio de produtos naturais, possa ter originado a correspondência trocada entre Domingos Vandelli e Sir Joseph Banks, presidente da Royal Society, bem como com o Real Jardim de Kew. ${ }^{30}$

A dificuldade de realizar recolhas de amostras vegetais explica que a já mencionada descrição da ipecacuanha, datada de 1698, se baseie numa memória francesa, comentada por Hans Sloane com base nos estudos de filosofia natural seiscentista de Piso, Marcgrave e Jean de Laet. $^{31}$ Também foi publicada, no volume correspondente a 1714-16, a opinião especializada do célebre Helvetius sobre a parreira brava - considerada como um poderoso auxiliar poderoso na digestão e diurético, vendida por altos preços nas boticas parisienses mais conceituadas com base numa carta enviada pelo médico francês como resposta a um pedido feito pelo Embaixador Extraordinário dos Estados Gerais, Mr. Duyvenvoorde, rapidamente transmitido à Royal Society. ${ }^{32}$

Só depois da abertura dos portos brasileiros à navegação internacional (1808) é que encontramos outra menção a um produto vegetal brasileiro: a cera de carnaúba foi estudada por William Thomas Brande com base numa amostra enviada do Rio de Janeiro pelo conde de Galveias a lord Grenville, primeiro-ministro do "Ministry of All Talents", e por este remetida a Sir Joseph Banks, presidente da Royal Society. ${ }^{33} \mathrm{O}$ estudo encomendado a Brande tinha como propósito averiguar se esta cera, originária do Rio Grande do Norte e Ceará, podia substituir a cera de abelhas na iluminação e se correspondia à descrita por Alexander von Humboldt e verificar um interesse prático: a sua utilidade na dinamização do comércio entre a colónia brasileira e a Grã-Bretanha. ${ }^{34}$

Esta breve incursão pelas escassas memórias das Philosophical Transactions relacionadas com o Brasil revela que, num dos centros intelectuais da Europa setecentista e num jornal destinado a divulgar junto de

autorização do Príncipe Regente e do financiamento do Erário Régio, as dificuldades encontradas pelos botânicos foram tais que Bowie foi enviado para o Cabo e Cunningham para Botany Bay, na Austrália (MACKAY, David. Agents of empire: the Banksian collectors and evaluation of new lands, p.45; DESMOND, Ray. The transformations of the Royal Gardens at Kew. In: ELLIOTT, Brent; HEWKES, JG; KING-HOLE, Desmond e LUCAS, GLP. Sir Joseph Banks: a global perspective. Kew: The Royal Botanic Gardens, 1994, p.108).

30 A existência desta correspondência é apontada por João Carlos Brigola que contudo não esclarece sobre o seu conteúdo (v. BRIGOLA, João Carlos. Museologia e História Natural em finais de setecentos - o caso do Real Museu e Jardim Botânico da Ajuda (1777-1808). In: Anais. Actas do Colóquio A Casa Literária do Arco do Cego, vol.VII-VIII, 2000-2001, p.219 e ss)

31 Sir Hans Sloane foi presidente da Royal Society entre 1727 e 1741.

32 An Extract of a Letter from Dr. Helvetius at Paris, to Monsieur Duyvenvoorde Embassador Extraordinary from the States-General, and by him communicated to the Royal Society. Philosophical Transactions, vol.29, p.365367, 1714-1716.

33 William Wyndham Grenville, Lord Grenville, foi Secretary of State for Foreign Affairs entre Abril de 1791 e Fevereiro de 1801.

34 BRANDE, William Thomas. An account of a vegetable wax from Brazil. Abstracts of the papers printed in the Philosophical Transactions of the Royal Society of London, vol.1, p.404-406, 1800-1814. Também há menção a esta experiência no Jornal de Coimbra, vol.1, p.10-11, 1812, e Instituto de Estudos Brasileiros, códice 76.1 e códice 2.A8 
um público especializado dados de natureza científica, se publicava pouco sobre a colónia brasileira na América do Sul. Do mesmo modo, a avaliar pelo conteúdo dos artigos publicados, o conhecimento que reflectiam era reduzido, desactualizado, fragmentário e insuficiente e não corresponderia certamente aos interesses da "elite of European scientists of the day" ligada à Royal Society, composta por selectos membros residentes e correspondentes espalhados por todo o mundo. ${ }^{35}$

Esta presença ténue da colónia brasileira, no entanto, dificilmente pode ser considerada como desinteresse por parte da comunidade intelectual. Com efeito, e não obstante todas as limitações intelectuais apontadas, redigiram-se na Inglaterra iluminista duas histórias da América que se propunham considerar a colónia portuguesa. A History of America, de William Robertson foi a primeira ${ }^{36}$. Editada em Londres, em 1777, incluía na introdução uma listagem bibliográfica reveladora da vontade inicial do autor em incluir no livro o Brasil. ${ }^{37}$ Esta intenção estava também patente nos contactos estabelecidos por Robertson com o embaixador Luís Pinto de Sousa Coutinho, que "was pleased to send me very full answers to some queries concerning the character and institutions of the native of Americas, which his polite reception of an application made to him in my name, encouraged me to propose". ${ }^{38}$ O projecto inicial viria a gorar-se, uma vez que nem a colónia portuguesa nem a inglesa foram estudadas na obra de Robertson. ${ }^{39}$

35 HUNTER, Michael. First steps in institutionalization: the role of the Royal Society of London. in Solomon's House revisited: the organizations and institutionalization of science. Canton/ MA: Science History Publications and the Nobel Foundations, 1990, p.26.

36 Nascido em 1721 e falecido em 1793. Era principal da Universidade de Edimburgo, historiador do rei para a Escócia, nomeado membro da Academia Real de História de Madrid em 1777. O seu livro foi traduzido rapidamente para francês, alemão e italiano. A edição espanhola contou com a oposição dos inimigos do Conde de Campomanes, presidente da Academia, que atacaram violentamente a obra. Foi proibida em Espanha por decreto real de 23 de Dezembro de 1778 e a sua divulgação impedida nas colónias espanholas americanas e nas Filipinas (HUMPHREYS, R. A. William Robertson and his History of América. Londres: The Hispanic \& Luso-Brazilian Councils, 1954, p.25-26).

37 As obras, ordenadas alfabeticamente, demonstram indiscutivelmente a intenção do autor: ALBUQUERQUE Duarte Coelho de. Memorial das Artes de Guerra del Brasil. Madrid, 1634; BARROS, João de. Décadas da Ásia. 4 vols. Lisboa, 1682; CASTANHEDA, Fernão Lopes de. História do descobrimento e da conquista da Índia pelos Portugueses (s.e., s,d,); Collecção de Breves Pontifícios e leis régias que foram expedidas e publicadas desde o anno de 1741 sobre a liberdade das pessoas, bens e comercio dos índios do Brasil; CORDEIRO, António. História Insulana das ilhas a Portugas (sic) sujeytas no Oceano Occidental. Lisboa 1717; FARIA e SOUSA, Manuel de. História del Reyno de Portugal. Antuérpia, 1730 e History of Portugal from the first Ages to the Revolution under John IV. Londres, 1698; GALVÃO, António. Tratado dos Descobrimentos antigos e moderno., Lisboa, 1731; Relación abbreviada da Republica que os Religiosos jesuítas estabeleceraom, (s.e., s.d.); OSÓRIO, Jerónimo de. History of the Portuguese during the reign of Emmanuel. 2 vols., Londres, 1752 e De rebus Emmanuelis Lusitaniae Regis, Col. Agr., 1572; ROCHA PITTA, Sebastião da. História da América Portuguesa; BERREDO, Bernardo Pereira de. Anais históricos do Estado do Maranhão. Lisboa, 1749; SILVA, José de Seabra da. Recueil chronologique \& Analitique de tout ce qu'a fait en Portugal la Societé dite de Jesus, depuis son entrée dans ce Royaume en 1540, jusqu'a son exulsion (1759). Lisboa, 1769; D. Thomas Tamaio de Verages, Restauracion de la ciudad del Salvador y Baia de todos Sanctos en la Provincia del Brasil. Madrid, 1648; VESPÚCIO, Américo. Navegatio prima, secunda, tertia, quarta. In: De Nov Orb Grynaei e Duae navigationes sub auspiciis Ferdinandi. In: DE BRY, América, Pars X.

38 ROBERTSON, William. The History of America. Londres: A Straham, Strand. T. Cadell, Edinburg, J Balfour, vol I, 5aㅡ edição, 1788, p.xiv.

39 R A Humphreys explica a decisão, atribuindo-a ao facto de: "the revolt of English colonies changed his mind (...) Nor did he have the energy to take up the Portuguese side of his story or the history of the European settlement in the West Indies". (HUMPHREYS, R. A. William Robertson and his History of America, p.13) 
O segundo projecto foi a History of Brazil de Robert Southey, considerada um êxito editorial: os quatro volumes que constituem a obra foram publicados entre 1810 e 1819 e uma segunda edição actualizada sai do prelo em 1822, confirmando-se, assim, a existência de uma audiência considerável composta por ingleses.

Southey é um caso que se distingue do universo até agora analisado. Ao contrário de Robertson, que planeava arquitectar a parte brasileira da sua History of America com a informação acessível a um súbdito britânico, Southey consultou, embora com as limitações anteriormente apontadas, documentação rara e original nas bibliotecas e arquivos portugueses, e muito particularmente na Biblioteca Nacional e Academia de Ciências de Lisboa. ${ }^{40}$ Para além disso, dispôs, ainda, dos manuscritos e impressos, muitos deles relacionados com o interior do Brasil e as minas de ouro, recolhidos pelo tio, Herbert Hill, capelão da comunidade inglesa em Lisboa e interessado bibliófilo. ${ }^{41}$

Um outro factor de interesse reside na dupla oportunidade da History of Brazil. Apesar de a sua génese remontar à segunda viagem de Southey a Portugal (1800-1801), a ideia ganhou uma dimensão diferente e a aprovação oficial do governo britânico em 1804, quando a Grã-Bretanha se decidiu por uma expansão territorial efectiva na América do Sul, com a ocupação de Buenos Aires (1804), um plano para atacar o Chile e expedições ofensivas ao rio da Prata. A obtenção de consideráveis benefícios económicos, relacionados com a prata do Potosi, as manadas platinas e as transacções de manufacturas com os ameríndios não andariam longe dos objectivos ingleses. ${ }^{42}$

Depois, é preciso ainda mencionar que esta história ficou acessível ao público a partir de 1810, ou seja, três anos depois de uma corte europeia, a primeira, mudar a sua residência para a colónia e dois anos depois da abertura dos portos brasileiros à navegação, ao comércio e aos estrangeiros com interesses científicos que quisessem viajar por um vasto espaço ainda não desvendado à maioria dos europeus.

É importante sublinhar, no entanto, que, as Histórias de Robertson e de Southey são projectos editoriais de natureza diferente das Philosophical Transactions: os primeiros, para além dos cientistas, abrangem um público mais vasto de curiosos, oriundos de grupos sociais interessados

40 È interessante mencionar que uma das fontes para o Norte brasileiro que aparece designada como Ribeiro foi por nós identificada como o Diário da viagem que em visita e correição das povoações do Rio Negro fez o Ouvidor e Intendente Geral da mesma no anno de 1774 e 1775 de Francisco Xavier Ribeiro de Sampaio, manuscrito só publicado pela Academia real das Ciências em 1825.

41 A biblioteca de Southey e a de Herbert Hill foram encaixotadas e enviadas para Londres face ao perigo da invasão espanhola, de facto ocorrida com a Guerra das Laranjas, em 1801 (HUMPHREYS, R. A. Robert Southey and his History of Brazil. Londres: The Hispanic and Luso-Brazilian Council, 1978, p.6 e 8).

42 Não deixa de ser interessante associar este projecto expansionista às instruções dadas por Herbert Hill para Southey disponibilizar ao primeiro-ministro inglês, Lord Grenville, os manuscritos relacionados com o interior do Brasil e as minas de ouro (HUMPHREYS, R. A. Robert Southey and his History od Brazil, p.8). 
nas relações económicas e políticas com as colónias americanas; o segundo é um jornal científico produzido por homens de ciência e dirigido a um grupo restrito e iniciado de académicos.

Nas memórias publicadas pelas Philosophical Transactions revelase uma curiosidade científica que transparece da recolha meticulosa de informações: traduziu-se para inglês a carta de Helvetius e o relatório do cavalheiro mineiro conhecido de Jacob Castro Sarmento; relatam-se experiências feitas com as amostras cedidas pelos fellows e pelo corpo diplomático português. Integram-se nos quadros académicos da Royal Society indivíduos que, de algum modo, estavam relacionados com a colónia, como Diogo de Mendonça Corte-Real, "a gentlemen very well versed in Natural History and who is about writing the Natural History of Brazil"; 43 Mateus Saraiva, cavaleiro da Ordem de Cristo, curioso de História Natural e Astronomia e médico do governador do Rio de Janeiro, admitido em 1743; ${ }^{44}$ ou ainda Luís Pinto de Sousa Coutinho que, às muitas qualidades que o recomendavam, adicionava o facto de ter sido governador de Mato Grosso entre 1769 e 1772.

A falta de notícias actualizadas e a escassez de informação podem atribuir-se, uma vez mais, como acima se referiu, ao controlo que o Estado Português queria manter em relação à sua colónia brasileira pelas razões já mencionadas. Contudo, se o secretismo das notícias sobre o Brasil fazia sentido enquanto razão de Estado, junto da corte de Lisboa ou dos governadores das capitanias do litoral ou continentais com fronteiras terrestres com a Hispanoamérica e a Guiana, se era justificado pelo receio fortemente sentido pelas autoridades administrativas e população de sofrer ataques marítimos e invasões terrestres; e se estes receios eram agravados pela precariedade do sistema de correios entre o reino e a colónia, que deixava os moradores ignorantes da política das casas reinantes europeias, dos jogos de poder diplomáticos e dos aliados ou dos inimigos do momento, muito pouca justificação teria para os ilustrados portugueses, homens de ciência e fellows, como Jacob de Castro Sarmento, João Jacinto de Magalhães ou José Correia da Serra, que viviam na capital londrina e tinham ligações profissionais, intelectuais e pessoais à comunidade científica internacional que constituía a "Republica das Letras" preconizada por Joseph Banks, enquanto presidente da Royal Society. Os segredos das minas de ouro e diamantes de Cerro Frio são duplamente desvendados por Castro Sarmento, que pri-

43 Diogo de Mendonça Corte-Real (1658-1736) era filho de Diogo de Mendonça Corte-Real e D. Jerónima de Lacerda. Foi ministro dos reis D. Pedro II e D. João V, enviado extraordinário aos Estados Gerais das Províncias Unidas, embaixador extraordinário na corte de Carlos $V$ e do Conselho Real. Foi também académico da Academia Real de História. Apesar de ser considerado como um homem culto, integro e inteligente, estranha-se o facto de se propor escrever uma História Natural do Brasil (SERRÃO, Joel. (dir) Dicionário de História de Portugal. Porto: Livraria Figueirinhas, vol. II, p.195). Foi integrado nos quadros da Royal Society em 1735.

44 Royal Society, Lista dos fellows da Royal Society. 
meiro traduz e depois submete à Society a publicação do relato; ${ }^{45}$ de igual modo, fellows como Emanuel Mendes da Costa teriam, desde meados do século, fornecido a Society com amostras de minerais do Brasil. 46

O secretismo era, de algum modo, posto em causa pelos diplomatas portugueses creditados na corte britânica, que por um lado eram homens de Estado e deviam fidelidade à monarquia portuguesa, por outro eram ilustrados e membros da Royal Society. Luís Pinto de Sousa Coutinho, representante diplomático em Londres em 1774, ministro plenipotenciário entre 1785 e 1788, admitido à Society em 1787, é um exemplo paradigmático da actuação equilibrada de um diplomata estrangeirado. Tendo um conhecimento exacto da geografia e da cartografia de limites do Brasil, participou de forma interessada e activa no mapa Columbia Prima or South America, desenhado por Louis Delarochette e impresso por William Faden em Londres, em 1807: "This map of the Continent of South America was originally undertaken by the advice of His Excellency the late Chevalier Pinto during his residence in London, as Minister Plenipotentiary from the Court of Portugal; who graciously patronized the work by communicating all the manuscript maps \& other geographical documents of the Portuguese Territories". ${ }^{47}$ Do mesmo modo, William Robertson obteve deste mesmo embaixador dados considerados de grande importância e utilidade sobre o carácter e as instituições dos ameríndios, informação que, como foi mencionado, se utilizou na History of América. $^{48}$

Uma questão que, no decorrer deste ensaio, se colocou foi a de como conciliar as restrições até aqui apontadas sobre a divulgação de notícias acerca da colónia sul-americana e a publicação de um número considerável de obras sobre o Brasil feito, entre outras, pelas Tipografia Calcográfica, Tipoplástica e Literária do Arco do Cego e Impressão Régia a partir de 1797. ${ }^{49}$ Uma solução satisfatória é apontada por José Luís Cardoso: tanto uma tipografia, como a outra eram projectos controlados por D. Rodrigo de Sousa Coutinho que, na sua qualidade de Secretário de Estado da Marinha e Domínios Ultramarinos (1796) e Presidente do Real Erário (1801), tinha competências para colocar sob sua orientação directa os trabalhos de criação e difusão técnica e científica das duas

\footnotetext{
45 Philosophical Transactions, vol. 37, p.199 e ss, 1731-32.

46 As primeiras experiências são publicadas no vol. 43, p.468-472, 1744-1745.

47 Biblioteca Nacional, Cartografia, CC. 126 R; ALMEIDA, André Ferrand de. Entre a Guerra e a Diplomacia: os conflitos luso-espanhóis e a cartografia da América do Sul. In: A Nova Lusitânia, p.63.

48 ROBERTSON, William. The History of America, p.xiii e xiv, 3 vol; ARMITAGE, David. The New World and British thought from Richard Hakluyt to William Robertson. In: KUPPERMAN, Karen Ordahl. America in European Consciousness 1493-1750. Chapell Hill/ Londres: University of North Carolina Press, 1995, p.52, p.66.

49 CAMPOS, Fernanda Maria e LEME, Margarida Ortigão Ramos Paes. Percursos do poder e do sabere nos finais do século XVIII: o papel da Impressão Régia e da Casa Literária do Arco do Cego. In: Anais. Actas do Colóquio A Casa Literária do Arco do Cego, p.111-123.
} 
editoras. ${ }^{50}$ Portanto, a impressão de obras sobre o Brasil era controlada pelo poder central que punha nitidamente a tónica em livros e folhetos de natureza utilitária e educativa destinados a desenvolver a agricultura e as indústrias reinóis e coloniais de forma racional, dinâmica e produtiva, seguindo os exemplos dados pelas 'nações civilizadas e cultas. ${ }^{51}$

O secretismo político defendido pela corte portuguesa deixava de fazer sentido em 1808, com a abertura dos portos brasileiros à navegação europeia e ao comércio estrangeiro. O acesso à colónia brasileira exploração mineralógica, inventariação das espécies e reconhecimento das potencialidades naturais - não só era franqueado sem restrições aos viajantes e naturalistas estrangeiros, como era incentivado e protegido pelo rei e seus ministros. ${ }^{52}$

Se no período compreendido entre 1808 e 1814 o tráfico comercial com os outros países da Europa cessou, (França, Holanda, Alemanha, Dinamarca) ou foi praticamente inexistente (Suécia, Prússia, Rússia), a dependência de Portugal e da colónia brasileira, tornada reino em 1817, em relação aos abastecimentos de manufacturas inglesas era grande. Para além disso, os britânicos monopolizavam, de forma quase absoluta, o transporte de mercadorias no Atlântico. ${ }^{53}$

Por outro lado, a medida legislativa que condenava o antigo sistema colonial português beneficiava claramente a Inglaterra. O comércio até aqui feito por intermédio de Lisboa e Porto ou efectuado ilegalmente através de contrabando realizava-se, depois de 1808, clara e legitimamente, favorecido ainda pelas isenções fiscais que beneficiavam em cerca de quinze por cento a comunidade mercantil inglesa. O Brasil representava para os britânicos um produtor de quantidades avultadas de bens coloniais, como o açúcar, algodão, cacau, tabaco e café, e um fornecedor vantajoso, sobretudo quando comparado à antiga colónia americana ou ao revoltoso Haiti. As experiências agrícolas realizadas com produtos nativos industrialmente inexplorados e a produção em larga escala de plantas aclimatadas oriundas de África e do Índico tornavam o Brasil num mercado atractivo aos olhos de homens de negócio e investidores britânicos.

As novas fibras têxteis e minérios representavam uma vantagem económica que os ingleses não queriam perder face à concorrência de outros países europeus. Este interesse económico teve repercussões de

50 CARDOSO, José Luís. D. Rodrigo de Sousa Coutinho, a Casa Literária do Arco da Cego e a difusão técnica e científica em Portugal. In: Anais. Actas do Colóquio A Casa Literária do Arco do Cego, p.198-199.

51 DOMINGUES, Ângela. Para um melhor conhecimento dos domínios coloniais: a constituição de redes de informação no Império Português em finais de Setecentos. Ler História, 39, p.28, 2000.

52 Esta questão foi desenvolvida em DOMINGUES, Ângela. Viagens científicas e divulgação cartográfica, p.76 ess.

53 PEDREIRA, Jorge A.. From growth to collapse: Portugal, Brazil and the Old Colonial system (1760-1830). Hispanic American Historical Review, nํ80, (4), Novembro de 2000. 
natureza científica, detectadas nas memórias publicadas nas Philosophical Transactions: as experiências científicas laboratoriais sem aplicação prática foram precedidas de outras que apontavam as vantagens comerciais dos novos produtos tropicais, como a cera de carnaúba. ${ }^{54}$

Não deixa de ser interessante mencionar que, em 1809, as Philosophical Transactions publicaram o artigo de William Hyde Wollaston, MD e FRS, intitulado On Platina and native Palladium from Brazil. ${ }^{55}$ Nele se relatavam as experiências feitas com base em amostras fornecidas pelo embaixador Domingos António de Sousa Coutinho em data indeterminada. ${ }^{56}$ Conhece-se bem a relutância de Wollaston em publicar a sua investigação sobre o palladium, no sentido de obter vantagens comerciais junto da colónia brasileira. A opinião de Joseph Banks acerca deste assunto é relatada em John Gascoigne: "The keeping of secrets among men of science is not the custom here /Royal Society/; \& those who enter into it cannot be considered as holding the same situation in the scientific world as those who are open \& communicative". ${ }^{57} \mathrm{O}$ resultado da pesquisa foi publicado!

\section{Os casos do Correio Braziliense e do Investigador Portuguez em Inglaterra}

As experiências de William Thomas Brande e William Hyde Wollaston publicadas nas Philosophical Transactions foram divulgadas em Portugal e no Brasil por dois jornais científicos: o Jornal de Coimbra e o Patriota, circulando por um número considerável de leitores nos dois lados do Atlântico. Este facto é revelador do movimento de abertura intelectual do Portugal de Setecentos e inícios de Oitocentos a uma Europa alicerçada no desenvolvimento económico e científico conduzido pela França e a Inglaterra, bem como da importância que neste processo teve a imprensa periódica e os jornais científicos e técnicos.

Depois do esforço de remodelação e actualização científica expresso nas reformas pombalinas e pós-pombalinas na área da educação e da ciência, dos patrocínios a bolseiros e dos convites a sábios e técnicos estrangeiros, a coroa portuguesa insistia ainda, nos inícios do século XIX, que "a necessidade que o Príncipe Regente Nosso Senhor considera de estender nos seus Estados as Luzes e Conhecimentos de todo o

\footnotetext{
54 BRANDE, William Thomas. An account of a vegetable wax from Brazil, p.404-406.

55 Wollaston seria presidente da Royal Society em 1820

56 Philosophical Transactions, vol.99, p.189 e ss, 1809; Domingos António de Sousa Coutinho (1762-1833) era irmão de D. Rodrigo de Sousa Coutinho e detentor de postos diplomáticos na Dinamarca, Turim, Roma e Inglaterra, onde foi ministro creditado entre 1803 e 1814.

57 GASCOIGNE, John. Science in the service of Empire: Joseph Banks, the British State and the uses of science in the Age of Revolution. Cambridge: Cambridge University Press, 1998, p.147.
} 
género tem feito nascer o dezejo das correspondências literárias que o mesmo senhor quer estabelecer entre os sábios da Europa e os de Portugal". ${ }^{58}$

A actualização científica institucional pressupunha que se tomassem por modelo os organismos congéneres existentes em outros países e se importassem obras científicas e técnicas europeias, bem como instrumentos de precisão. Caixotes de livros e mapas importados de Londres e Paris guarneceram as estantes da Sociedade Real Marítima e Geográfica; contactos com a comunidade científica europeia continuaram a ser feitos através do corpo diplomático creditado nas principais capitais europeias ou da correspondência trocada entre homens de ciência, directores de universidades, academias e instituições científicas. ${ }^{59}$

Por seu turno, o reconhecimento da produção científica implicava a sua divulgação e revalidação pela comunidade científica internacional. Inúmeros cientistas portugueses, como Teodoro de Almeida, Francisco de Borja Garção Stocker, José Anastácio da Cunha, e instituições como, por exemplo, a Academia de Ciências de Lisboa, enviavam as suas publicações para o estrangeiro; ${ }^{\circ}$ a Sociedade Real Marítima e Geográfica remetia as Efemérides do padre J. M. Monteiro da Rocha a Lalande, em Paris, a Zach em Gotha e ao astrónomo real Nevil Maskelyne, em Greenwich. ${ }^{61}$

Contudo, os inícios do século XIX trouxeram grandes aditamentos a este panorama, com o grande salto despoletado por particulares - predominantemente intelectuais burgueses nascidos nas colónias sul-americanas - que utilizaram os jornais para tornar o conhecimento científico acessível a um público mais vasto. Se a ciência continuou a ser feita nos gabinetes e laboratórios e a ser validada pela 'academia de sábios', rapidamente deixaria de ser exclusiva das elites aristocráticas para se tornar perceptível a uma audiência mais vasta, interessada, curiosa, ligada a uma burguesia endinheirada mercantil e ligada aos novos 'saberes técnicos e interessada em promover-se culturalmente. ${ }^{62}$

58 Sociedade de Geografia de Lisboa, Sociedade Real Marítima e Geográfica, Reservados, 146, Maço 5, no 29, doc. 18, Ofício de D. Rodrigo de Sousa Coutinho a Francisco de Paula Travassos, de Junho de 1802.

59 CUNHA, Rosalina. Documentos diversos sobre a Sociedade Real Marítima, Militar e Geográfica, 1798-1809. Separata de Ocidente, vol. LXXII, p.57, 1967.

60 Cf., por exemplo, as listas de "Presents received by the Royal Society" apensas aos volumes das Philosophical Transactions, particularmente vols. 92 (1802), 98 (1808), 104 (1814), 108 (1818), 109 (1819), 110 (1820), 112 (1822) e 113 (1823).

61 Sociedade de Geografia de Lisboa, Sociedade Real Marítima e Geográfica, Reservados 146, Maço 5, ㄲo 29 , doc. 30, Rascunho de ofício de Francisco de Paula Travassos, secretário da Real Sociedade Marítima, Lisboa, s.d.; Nevil Maskelyne era astrónomo e matemático. Foi nomeado astrónomo real em 1765, autor de cerca de 90000 observações astronómicas publicadas e do Nautical Almanac, considerado por Maskelyne e seus discípulos como um instrumento indispensável à navegação (O'BRIAN, Patrich. Joseph Banks. A life. Londres: The Harvill Press, 1989, p.248.

62 LOUSADA, Maria Alexandre. Espaços de sociabilidade em Lisboa: finais do século XVIII a 1834. dissertação de doutoramento em Geografia Humana apresentada à Faculdade de Letras da Universidade de Lisboa. Lisboa, 1995, p.337; TENGARRINHA, José. História da imprensa periódica em Portugal. Lisboa: Portugália Editora, s.d., p.45 
A discussão das novas ideias científicas e políticas desceu das academias e dos salões para espaços menos aristocráticos como os cafés e as tabernas. Alastrou a um público diferente que tinha fácil acesso a jornais, folhetos e panfletos que se podiam comprar, alugar ou simplesmente ler em gabinetes de leitura. ${ }^{63}$

Tal como afirma José Tengarrinha, o jornalismo português dos primeiros anos do século XIX dificilmente desempenharia o papel de primeiro plano que tinha na Inglaterra, Holanda e França ${ }^{64}$ Este fenómeno explica-se, primeiro que tudo, pela actividade da censura e vigilância exercida sobre qualquer tipo de publicações, bem como pelos privilégios e regalias de algumas publicações periódicas e casas de impressão; e, em segundo lugar, pela desvinculação de figuras de vulto relacionadas com a vida política e intelectual portuguesa que conotavam este tipo de literatura como um produto para um público de baixa extracção social e cultural. ${ }^{65}$

Apesar de a quantidade de periódicos editados em Portugal ser considerável até 1811, muito poucos perduraram até finais do decénio seguinte e a maioria caracterizava-se pela falta de dinamismo ou por serem instrumentos de propaganda, um "meio eficiente de agitação e mobilização" ao serviço do poder político pró ou anti-napoleónico. ${ }^{66}$ A literatura patriótica panfletária publicada por essa altura incluía folhas anónimas, folhetos, sermões, discursos, peças de teatro e poesia destinadas a inflamar o ânimo dos populares contra ou a favor do exército francês. ${ }^{67}$

Londres foi o primeiro e principal emissor de panfletos contra Napoleão, assim como Portugal foi um dos canais que permitiu a propagação desta literatura a Espanha e ao resto do continente. Do mesmo modo, a capital londrina foi o local de produção de uma literatura periódica portuguesa que, surgindo a coberto do clima de guerra aberta sentido nos inícios do século, apontou cruamente os problemas sociais, económicos e políticos protagonizados pelo regime absolutista. Tal foi o caso do Correio Braziliense, de Hipólito José da Costa Pereira Furtado de Mendonça e de $O$ Investigador Portuguez em Inglaterra, dirigido por Vicente Pedro Nolasco da Cunha e Bernardo Abrantes de Carvalho, considerados como

63 Muitos destes gabinetes possuíam para além de livros e viagens, novelas, poemas, obras sobre economia, jornais nacionais e estrangeiros (LOUSADA, Maria Alexandre. Espaços de sociabilidade em Lisboa: finais do século XVIII a 1834,p.352-354 e 360).

64 TENGARRINHA, José. História da imprensa periódica em Portugal, p.40.

65 Tengarrinha aponta como excepções os casos de António de Sousa Macedo e de José Agostinho de Macedo e como a antítese o caso de Inglaterra, onde a imprensa tinha a colaboração regular de figuras conceituadas (TENGARRINHA, José. História da imprensa periódica em Portugal, p.45).

66 VICENTE, António Pedro. Panfletos anti-napoleónicos durante a Guerra Peninsular. Actividade editorial da Real Imprensa da Universidade. Revista de História das Ideias, vol.20, p.101 e ss, 1999.

67 BERNARDINO, Teresa. Sociedade e atitudes mentais em Portugal (1777-1810). Lisboa: Imprensa NacionalCasa da Moeda, 1986, p.192. 
os jornais mais importantes e lidos que escapavam às imposições ditadas por Lisboa. ${ }^{68}$

Neste momento, entendemos que, mais do que pretender uma análise formal dos periódicos e perceber as interligações estabelecidas entre a imprensa de emigração londrina e os jornais portugueses e brasileiros, importa perceber qual o grupo que os origina e que ligação têm à Grã-Bretanha.

À semelhança do que tinha acontecido em períodos anteriores, o Reino Unido acolheu uma significativa comunidade de intelectuais portugueses nos inícios do século XIX. Alguns faziam a sua grand tour ou tour philosophique pela Europa e, com o objectivo de completarem a sua formação, demoravam-se num dos centros de maior produção intelectual e maior prestígio da Europa; outros seriam, sem dúvida, estudantes em universidades inglesas, como atesta o caso do Dr. Castro, apontado por Inocêncio como sendo um dos fundadores de $O$ Investigador Portuguez em Inglaterra. Mas, à semelhança do que tinha ocorrido com Jacob de Castro Sarmento, muitos encontravam em Londres um local de acolhimento às perseguições que Ihes eram movidas. Este foi o caso de Vicente Nolasco da Cunha, que despertou a ira de Junot por ter brindado à Casa de Bragança e ao príncipe regente durante uma solenidade ao tempo em que era presidente de uma loja maçónica lisboeta; ${ }^{69}$ de Bernardo José de Abrantes e Castro, fugido dos cárceres da Inquisição, onde tinha sido preso por acusação de jacobino e maçon; ${ }^{70}$ de Silvestre Pinheiro Ferreira, constrangido a deixar a Universidade de Coimbra devido à ameaça constituída pelas acusações de jacobino, espírito forte e conspirador; ${ }^{71}$ e, ainda de Hipólito José da Costa Pereira Furtado de Mendonça, também ele fugido aos cárceres inquisitoriais onde estava preso por ordem de D. Rodrigo de Sousa Coutinho sob a acusação de maçon. ${ }^{72}$

Instalados em Londres, estes indivíduos, oriundos do reino e do Brasil, detentores de um grau académico conferido por uma universidade ou uma instituição eclesiástica de prestígio, consolidavam a sua rede de ligações: com outros portugueses recém-emigrados, o corpo diplomático residente, os refugiados liberais espanhóis e os separatistas sul-ame-

68 LISBOA, João Luís. Ciência e política. Ler nos finais do Antigo Regime. Lisboa: INIC, Centro de História da Cultura da Universidade Nova de Lisboa, 1991, p.180.

69 SILVA, Inocêncio Francisco da. Diccionário Bibliográfico Portuguez, .vol.VII, Vi, p.434

70 SILVA, Inocêncio Francisco da. Diccionário Bibliográfico Portuguez, vol. I, Be, p.379.

71 SILVA, Inocêncio Francisco da. Diccionário Bibliográfico Portuguez, vol.VII, Si, p.259; cf. SILVA, Maria Beatriz Nizza da. Silvestre Pinheiro Ferreira: ideologia e teoria. Lisboa: Livraria Sá da Costa, 1975.

72 Era filho de Félix da Costa e de Ana Josefa Pereira, nascido em Sacramento a 1774. Ingressou na Universidade de Coimbra em 1792, onde obteve o grau de bacharel em Direito e Leis em 1797 e em doutor em Filosofia em 1796 (SILVA, Inocêncio Francisco da. Diccionário Bibliográfico Portuguez, vol.III, Hy, p.198; MONTEIRO, Rolando. Hipólito da Costa e a independência. Documentário e apreciação. Rio de Janeiro/ Brasília: Livraria Editora Cátedra e Instituto Nacional do Livro, 1979). 
ricanos, vindo, assim, a engrossar as comunidades de ibéricos e latinoamericanos residentes em Londres, que estudavam e publicavam livros, artigos e revistas que expressavam as suas preocupações políticas, científicas, sociais e econômicas. ${ }^{73}$

Estas redes constituídas pelas ligações pessoais dos emigrados reflectem-se nos jornais a nível ideológico, nos pedidos de colaboração e nos patrocínios. Tome-se como exemplo o Investigador Portuguez em Inglaterra: este jornal resultou da associação de dois reinóis e um lusobrasileiro (o dr. Castro), dois formados em medicina pela Universidade de Coimbra e o outro pela Universidade de Edimburgo. O projecto editorial contou com o patrocínio financeiro da coroa que expressava, desta forma, a protecção oficial dada por D. Rodrigo de Sousa Coutinho e Domingos António de Sousa Coutinho, ao tempo embaixador na corte britânica. Embora o conde de Palmela, cumprindo ordens de Tomás António de Vila Nova Portugal, tivesse cortado o subsídio, subsistiu até 1819, graças às subscrições de particulares residentes em Inglaterra, Portugal e Brasil. ${ }^{74}$ Destinado a servir declaradamente propósitos de ordem política na defesa dos interesses da monarquia portuguesa face às acusações do Correio Braziliense, passou, com a inclusão de José Liberato Freire de Carvalho, a censurar a actuação da monarquia portuguesa, acusada de tratar o reino como colónia e de não dar a Portugal "leis compatíveis com a sua situação e até com as luzes do século". ${ }^{75}$ Não obstante, concebia-se como um jornal de divulgação técnica e científica, editando estudos de ciências naturais, medicina e notícias e criticas de obras efectuados em Portugal e no Brasil ou publicados na Europa. Por isso, o principal órgão interlocutor foi o Jornal de Coimbra, editado por José Feliciano de Castilho, Ângelo Ferreira Dinis e Jerónimo Joaquim de Figueiredo e especializado em "ciências físicas e morais, as artes, e a historia topográfica civil, archeologica e litterária de Portugal e seus domínios" com o qual O Investigador Portuguez estabeleceu uma comunicabilidade científica facilmente detectável. ${ }^{76}$

Atente-se também no caso do Correio Braziliense, dirigido por Hipólito José da Costa Pereira Furtado de Mendonça, entre 1808 e 1822. Atra-

73 LÉON, Maria Teresa Berruezo. La lucha de Hispanoamérica por su independencia en Inglaterra, 1800-1830. Madrid: Edicones de Cultura Hispanica, 1989, p.21-22.

74 LOUSADA, Maria Alexandre. Espaços de sociabilidade em Lisboa, p.344-345. CARVALHO, José Liberato Freire de. Memórias da vida de José Liberato Freire de Carvalho. Introdução de João Carlos Alvim. Lisboa: Assírio e Alvim, 1982, p.94.

75 CARVALHO, José Liberato Freire de. Memórias da vida de José Liberato Freire de Carvalho, p.92.

76 SILVA, Inocêncio Francisco da. Diccionário Bibliográfico Portuguez, vol.IV, p.177-178; NUNES, Maria de Fátima. Leitura e agricultura. A imprensa periódica científica em Portugal /1772-1852), 2 vols. Évora, Dissertação de doutoramento apresentada à Universidade de Evora em História Cultural Moderna e Contemporânea, 1994, p 201; MACHADO, Adelaide Vieira. O Investigador Portuguez em Inglaterra nos primeiros anos da sua publicação (1811-1813). Lisboa, dissertação apresentada à Faculdade de Ciências Sociais e Humanas da Universidade Nova de Lisboa, Mestrado em História Cultural e Política, 1996, p.133; LISBOA, João Luís. Ciência e política. Ler nos finais do Antigo Regime, p.69. 
vés deste jornal o editor expressou um plano de reformas radicais, por ele consideradas indispensáveis à felicidade da nação: a nível administrativo, no comércio, acerca do pacto colonial, nas relações entre a monarquia portuguesa e os países estrangeiros, no fomento da agricultura e no desenvolvimento da indústria. ${ }^{77}$ Defendeu, de forma exacerbada, a independência brasileira e o constitucionalismo e, por isso, não parece estranho que um dos colaboradores do Correio Braziliense tenha sido o hispânico Francisco de Miranda, tradutor de uma sinopse intitulada Emancipation of Spanish America e autor de cartas sediciosas enviadas às capitais sul-americanas incitando à autonomia política as colónias espanholas, aliás publicadas no Correio Braziliense. ${ }^{78}$

Não deixa de ser interessante notar que, apesar de a Inglaterra ser um país tradicionalmente aliado de Portugal e ao lado do qual a monarquia portuguesa se colocou abertamente contra o bloqueio continental imposto por Napoleão, aí se publicavam jornais que criticavam a actuação do governo português e advogava a independência da colónia americana. ${ }^{79}$ As limitações postas às publicações portuguesas editadas em Inglaterra surgiram unicamente por parte do governo português. Este é o caso de O Investigador Portuguez em Inglaterra. Houve uma clara tentativa de censura quando o então embaixador em Londres conde de Palmela - largamente criticado por José Liberato Freire de Carvalho pela sua actuação no Congresso de Viena - , propôs ao editor do jornal que os artigos de índole política fossem "aqui combinados na minha secretária". ${ }^{80}$ A proposta era legitimada a pretexto do subsídio governamental concedido pelo governo português e foi recusada por José Liberato que continuou a publicar artigos de opinião censurando a presença e a actuação da monarquia portuguesa no Rio de Janeiro.

A publicação da imprensa periódica da emigração foi contemplada com benevolência por parte das autoridades londrinas. Tal explica-se, em primeiro lugar, porque a tradição britânica permitia a publicação de literatura política sem qualquer actividade de vigilância e censura. $\mathrm{O}$ governo inglês, na defesa de certos direitos e da liberdade de imprensa, não reprimia ou censurava os ataques dirigidos pela imprensa publicada nesse país contra os soberanos e nações estrangeiros, mesmo se aliados. ${ }^{81}$ Depois, é preciso considerar que, numa Europa em que muito

77 FERREIRA, João Pedro Rosa. O jornalismo na emigração. Ideologia e política no Correio Braziliensa, 18081822. Lisboa: INIC, Centro de História da Cultura, Universidade Nova de Lisboa, 1992, p.21.

78 LÉON, Maria Teresa Berruelo. La lucha de Hispanoamérica por su independencia en Inglaterra, p.75.

79 Sobre as implicacõos a vários níveis das relações de Portugal com Inglaterra cf. CURTO, Diogo Ramada. D. Rodrigo de Sousa Coutinho e a Casa Literária do Arco do Cego. In: A Casa Literária do Arco do Cego (17991801). Bicentenário. "Sem livros não há instrução». Lisboa: Biblioteca Nacional, Imprensa Nacional-Casa da Moeda, 1999, p.16 e ss.

80 CARVALHO, José Liberato Freire de. Memórias da vida de José Liberato, p.94.

81 MARINUS, Jean-François. Pratique britannique face aux offenses écrites envers les souverains étrangers à la fin du XVIIle et au début du XIXe siècles. Annales historiques de la Révolution Française, № 335, p.131, Janvier-Mars 2004. 
pouco se conhecia sobre a América Latina, as notícias divulgadas e, eventualmente, publicadas por indivíduos oriundos ou relacionados com a colónia portuguesa contribuíam para uma aproximação cognitiva à mesma e eram de interesse comum e podiam, como já foi referido, ser utilizadas para obter vantagens comerciais. De igual modo, um apoio, ainda que ténue, à causa dos emigrados luso-brasileiros podia significar, se o Brasil optasse pela autonomia política num futuro que se adivinhava próximo, uma posição vantajosa para negociar acordos políticos e comerciais face a outros países europeus - e muito particularmente a França. ${ }^{82}$

Portanto, em Inglaterra, os emigrados portugueses e luso-brasileiros, muitos deles perseguidos pelas autoridades lusitanas por questões políticas ou ideológicas, publicavam livremente jornais destinados a esclarecer, formar e actualizar os povos, tanto o português como o brasileiro. A sua actividade tinha implícita uma noção de utilidade social, de educação dos povos com vista ao progresso, à felicidade e ao bem comum. Na medida em que estavam fisicamente próximos dos centros de maior desenvolvimento intelectual e científico situados numa das maiores potências europeias do século XIX, também ela berço da Revolução Industrial, e que podiam exercer a sua actividade sem as limitações e peias importas pela censura metropolitana, consideravam-se como mais habilitados para esclarecer politicamente os povos e apontar os caminhos para alcançar o desenvolvimento económico e político.

Tomando por base os princípios ideológicos e programáticos do Investigador Portuguez, se o reino se encontrava devastado pelos horrores da guerra e a colónia se apresentava como um continente rico e imenso mas subaproveitado e subdesenvolvido, o jornal propunha-se "colligindo as luzes da Europa e reflectindo-as até às Regioens Equatoriais (...) mostrar, dentro dos limites, tanto os traços da história do tempo, como os brilhantes productos da Literatura geral. As Sciencias serão por elle exhibidas em todo o lustre de seos progressos actuaes e na sua importante applicação à utilidade geral". ${ }^{83}$ Do mesmo modo, o Correio Braziliense considerava como dever de todos os indivíduos, em função das suas forças físicas e talentos específicos, contribuir para o bem geral da sociedade: "as luzes que elle espalha tiram das trevas ou da illu-

82 Um exemplo desta atitude política britânica pode ser detectado no Viscount de Strangford, embaixador britânico creditado junto da corte do Rio de Janeiro entre 1807 e 1810 (e mais tarde entre 1828 e 1830), um dos diplomatas mais escutados e acatados, que desenvolvia uma política de apoio aos movimentos revolucionários e pró-independentistas sul-americanos, destinada a, futuramente, favorecer economicamente o seu país (VICENTE, António Pedro. Política exterior de D. João VI no Brasil. Estudos avançados, 7 (19), p.203, 1993.); sobre a importância de Lord Strangford na corte do Rio de Janeiro ver também PRESAS, José. Memórias secretas da Princesa do Brasil. Introdução de Horacio Zorraquín Becú. Buenos Aires: Editorial Huarpes, 1948.

$83 \mathrm{O}$ Investigador Portuguez em Inglaterra, vol.I, 1811, p.2. 
são aquelles que a ignorância precipitou no labyrintho da apathia, da inépcia e do engano (...). Longe de imitar só o primeiro despertar da opinião pública nos factos que excitam a curiosidade dos povos, quero, alem disso, traçar as melhorias das Sciencias, das artes e, n'uma palavra, de tudo aquillo que pode ser útil à sociedade em geral". ${ }^{84}$

Não obstante os esforços desenvolvidos pela censura portuguesa para proibir a leitura do Correio Braziliense, combatido por folhetos de Joaquim de Santo Agostinho Brito França Galvão e José Joaquim de Almeida e Araújo Correia de Lacerda e oficialmente determinada por decisão real em 17 de Setembro de 1811,85 seguido de O Investigador Portuguez depois da radicalização da posição política de José Liberato Freire de Carvalho após a saída de Sousa Coutinho das funções de embaixador, estes jornais eram avidamente lidos em Portugal e no Brasil, talvez até com mais interesse e entusiasmo que anteriormente, por uma elite intelectual e burguesa aglutinada em torno da riqueza, do saber e do progresso, nem sempre submetida às directrizes impostas pelo Estado. ${ }^{86}$

Aos dois se opôs violentamente José Agostinho de Macedo, inimigo de longa data de José Liberato. Ao Correio Braziliense, considerado como o papel mais incendiário do mundo, criticava o facto de o jornal querer "que tudo quanto se faz, se diz, se determina em economia, em política, em legislação, em milícia, em literatura neste Reino de Portugal (...) seja huma parvoíce". ${ }^{87}$ Ao Investigador Portuguez em Inglaterra apontava o facto de ser simpático às causas independentistas americanas e de ser desactualizado, de valor nulo e sedicioso: "he em notícias de tempo, pois sempre vem com humas de ancianidade que bem podem entrar só no Gabinete dos Quinhentistas; he perigoso em politica, pois se conserva neste que o artigo Caracas e seus anexos he mais extenso que todos os outros e se não dá lições abertas de insurreição põe diante dos olhos os exemplos que sendo maos, são as peores lições; he ocioso em literatura porque nenhum proveito se pode tirar de hum ou outro pedaço des-

84 Correio Braziliense ou Armazém Literario, vol. I, Junho 1808, p.3.

85 Joaquim de Santo Agostinho Brito França Galvão era eremita de Santo Agostinho, licenciado em Teologia sócio da Academia de Ciências de Lisboa e deputado às cortes ordinárias de 1922-23. Foi agraciado com a Ordem de Avis. Escreveu as GALVÃO, Joaquim de Santo Agostinho Brito França. Reflexões sobre o Correio Braziliense. Lisboa: Impressão Régia, 1809; José Joaquim de Almeida e Araújo Correia de Lacerda foi do Conselho de Estado, do Conselho do Rei D. João VI, ministro e secretário de Estado dos Negócios do Reino, secretário da Junta e Estado da Casa de Bragança e o autor de Exame dos artigos históricos e políticos que se conteem na colecção periódica intitulada Correio Braziliense no que pertençe somente ao reino de Portugal. Lisboa: Imprensa Régia, 1810 (SILVA, Inocêncio Francisco da. Diccionário Bibliográfico Portuguez,, vol. IV, J p.57-58, p.381)

86 Afinidades desde público com o caso americano podem ser encontradas em LÉON, Maria Teresa Burruezo. La lucha de Hispanoamérica por su independencia en Inglaterra e em RUIZ-BARRIONUEVO, Carmen. La cultura ilustrada de José Joaquin Fernandez de Lizardi. Anuario de Estudios Americanos. Suplemento, Sección Historiografica y Bibliografica, tomo XLVIII, nำ2, p.77, 1991.

87 MACEDO, José Agostinho de. Carta de hum pai para seu filho, estudante na universidade de Coimbra, sobre o espírito do Investigador Portuguez em Inglaterra. Lisboa: Impressão Régia, 1812, p.12. 
tacado de qualquer obra que não continua nem se apresenta ao menos o espírito ou a substância; he infructuoso nos documentos da nossa literatura, porque havendo tantos materiais para construir e para completar este edifício, elle os ignora e estão dependentes que daqui lhe remettão ao acaso algum papel que todos tem em Portugal; he perigoso desde agora porque quem aqui não pode atacar ou insultar pela prensa hum inimigo acha estes Senhores promptissimos para publicarem satyras afrontosas com manifesto insulto das Leis deste Reino" . ${ }^{88}$

A ida da família real para o Brasil evitou que a colónia enfrentasse as incertezas e a instabilidade conhecidas por outros países sul-americanos. Permitiu também que um príncipe português se estabelecesse no Brasil e se tornasse o primeiro imperador de um novo império em 1822. Neste processo, a elite composta por um pequeno número de indivíduos formados nas universidades do reino ou no estrangeiro, que utilizava a imprensa como forma de criar uma consciência política entre os povos, contribuiu, directa ou indirectamente, na criação de um sentimento de identidade comum e teve um papel significativo na manutenção da coesão política da antiga colónia brasileira. ${ }^{89}$

88 MACEDO, José Agostinho de. Carta de hum pai para seu filho, p.39; v. também idem, Resposta aos dois do Investigador Portuguez em Londres que no caderninho VIII, a Páginas 510 atacão, segundo o costume, o poeta Gama. Lisboa: Impressão Régia, 1812.

89 KIRKENDALL, Andrew J. Classmates. Male student culture and the making of a political class in nineteenth century Brazil. Lincoln/ Londres: University of Nebrasca Press, 2002, p.4. 